\title{
Psychological Capital and Job Performance: The Mediating Role of Work Attitudes
}

\author{
U. W. M. R. Sampath Kappagoda1, Hohd Zainul Fithri Othman², Gamini De Alwis ${ }^{3}$ \\ ${ }^{1}$ Doctoral Student, School of Graduate Studies, Management and Science University, Shah Alam, Malaysia \\ ${ }^{2}$ Management and Science University, Shah Alam, Malaysia \\ ${ }^{3}$ University of Colombo, Colombo, Sri Lanka \\ Email: sampathkappagoda@gmail.com
}

Received 26 April 2014; revised 27 May 2014; accepted 10 June 2014

Copyright (C) 2014 by authors and Scientific Research Publishing Inc.

This work is licensed under the Creative Commons Attribution International License (CC BY).

http://creativecommons.org/licenses/by/4.0/

(c) (i) Open Access

\section{Abstract}

The purpose of this study was to investigate the relationships among Psychological Capital (PsyCap), work attitudes and job performance of the employees in the banking sector in Sri Lanka. The sample consisted of 176 managers and 357 non-managerial employees. A questionnaire was administered among the employees as the measuring instrument. The collected data were analyzed using correlation coefficient and regression. The results of the study indicated that there was a significantly positive relationship between PsyCap and job performance, PsyCap and work attitudes, work attitudes and job performance. Work attitudes were found to mediate the relationship between PsyCap and job performance of the employees in the banking sector in Sri Lanka.

\section{Keywords}

\section{Psychological Capital, Job performance, Work attitudes, Mediating Effect}

\section{Introduction}

The banking sector is the dominant sub sector within the financial sector in Sri Lanka. Banks play a vital role in shaping up the economy of any country. The failure of a single bank can lead to the failure of the entire economy. The overall performance of the banking sector directly affects the other industrial and service sectors of the economy. The success of the banking sector as a service organization largely depends on the customer satisfaction. The employees are the key factor in providing better service to their customers and ultimately it helps to improve the overall performance of the banks. The bank employees play an important role in delivering high quality services, promoting the corporate image and improving customer satisfaction (Karatepe and Tekinkus, 2006) [1]. According to Gabbott and Hogg (1997), employees’ Job Performance (JP) is a key individual out- 
come in the financial and banking sector [2]. Thus, the enhancing the JP of the employees is a high priority of any manager in the banking sector.

In reviewing the theoretical and empirical evidence, researchers have identified different factors that can be affected for JP. Some researchers pointed out the importance of positive psychological capabilities of the people as a new approach to enhance the JP of the employees after extended the concepts of positive psychology into the work place. Among them a newly developed concept of PsyCap has been given much attention in the recent past. Luthans and colleagues define PsyCap as an individual's positive state of development characterized by hope, confidence, optimism and resilience (Luthans, Luthans, \& Luthans, 2004) [3]. Most of the research in PsyCap has been conducted by Luthans and his colleagues in the United State and China showed the positive relationship between PsyCap and JP. There have been relatively few empirical studies on PsyCap in Asia. However in Sri Lankan context up to date this relationship has not been tested. In turn, the work attitudes of the Sri Lankan people are different from those of other countries. Therefore, it is not reasonable to predict a similar relationship between PsyCap and JP as it is in the other countries.

Work attitudes are an individual's general attitude towards his or her job and the organization. The majority of the researchers have found Job Satisfaction (JS) and Organizational Commitment (OC) as two important work attitudes in the organization. JS is a subjective measure of worker attitudes, that is, an individual's general attitudes to his or her job (Robbins, 2003) [4]. OC is the psychological attachment or effective commitment formed by an employee in relation to his/her identification and involvement with the respective organization (Porter et al., 1974) [5]. It is an individual's feelings of attachment and connection toward their organization. JS and commitment are said to be antecedents for a wide range of desirable organisational outcomes such as JP and absenteeism as well as turnover intentions (Chugtai \& Zafar, 2006) [6]. Various studies have examined the relationship between PsyCap and employee-related attitudes. A meta-analysis conducted by Avey et al. (2011) has illustrated that PsyCap has been positively related to desirable employee attitudes and negatively related to undesirable employee attitudes [7].

In reviewing the literature, there exists a substantial amount of research on the relationship between PsyCap and JP whereas some researchers have found direct relationships between PsyCap and work attitudes and work attitudes and JP. Anyway, the mediating effect of work attitudes on the relationship between PsyCap and JP has not been examined in previous researches. In the review of existing research literature in Sri Lanka, up to date, any research has not been conducted in any context on the consequences of PsyCap or the mediating effect of work attitudes on the relationship between PsyCap and JP.

\subsection{Problem Statement}

Some researchers have found direct relationship between PsyCap and JP. In turn, relationships between PsyCap and work attitudes, work attitudes and JP have been empirically established. In reviewing the literature, there were no researches on the direct impact of PsyCap on JP or the mediating effect of work attitudes on the relationship between PsyCap and JP in Sri Lanka. Therefore, the problems addressed in this study are to investigate:

1. How and in what ways does PsyCap influence JP in the banking sector in Sri Lanka?

2. How and in what ways do work attitudes influence JP in the banking sector in Sri Lanka?

3. How and in what ways does PsyCap influence work attitudes in the banking sector in Sri Lanka?

4. Do work attitudes mediate the relationship between PsyCap and JP in the banking sector in Sri Lanka?

\subsection{Objectives of the Study}

1. To identify the relationship between PsyCap and JP of the employees in the banking sector.

2. To investigate the impact of PsyCap and work attitudes of the employees in the banking sector.

3. To identify the relationship between work attitudes and JP of the employees in the banking sector.

4. To identify the mediating effect of work attitudes on the relationship between PsyCap and JP among the employees in the banking sector.

\section{Literature Review}

\subsection{Psychological Capital}

Luthans and colleagues developed the concept of Psychological Capital (PsyCap) (Luthans et al., 2007) [8]. 
They define PsyCap as "an individual's positive psychological state of development characterized by self-efficacy, hope, optimism and resilience”. PsyCap is positively and uniquely related to the field of organizational behavior because it is based on theory and research, measurable, state-like or open to development, and related to positive work outcomes (Luthans, 2002) [9] [10]. PsyCap as well as each of its constituent resources have been considered as state-like in the positive psychological literature (Bandura, 1997 [11]; Masten \& Reed, 2002 [12]; Luthans, 2002 [9] [10]). According to theoretical and empirical evidence, it can be concluded that PsyCap as a second order core construct (Luthans et al., 2007) [8]. The first and most theoretically developed and researched dimension of Psyap is self-efficacy. It has been received more research support. This dimension has been best matched with all the POB criteria (Luthans, 2002) [9]. Stajkovic and Luthans (1998) defined the concept of self-efficacy relevant to work place as person's confidence of his or her abilities to make ready for the motivation, cognitive resources and a way of acting necessary to effectively perform a specific task within a certain context [13]. According to Snyder and colleagues (1991) [14] hope is a "positive motivational state that is based on an interactively derived sense of successful." It is also included agency and pathway components. Agency is goal directed energy and pathway means planning to achieve goals. Snyder (2000) defined hope as "both the willpower (agency) and way power (pathways) that you have for your goals" [15]. It is the will for desired goal (Snyder, 2000 [15]; Snyder et al., 1996 [16]). The pathways component of this definition involves the alternative ways and contingency plans to reach those goals as they forecast obstacles to achieve the expected goals (Snyder, 1996 [17], 2000 [15]). According to Snyder, (2000) [15] agency and pathways thinking are interrelated and operate in a combined, iterative manner to generate hope. In general, optimist is a person or positive thinker who expects good things to happen while a pessimist expects worse (Carver et al., 2005) [18]. Anyway, in positive psychology based on empirical theory and research it has a specific meaning. Tiger (1979) [19] defined optimism as a mood or attitude associated with an expectation about the social or material future, one which the evaluator regards as socially desirable, to his or her advantage, or for his or her pleasure. Seligman's explanatory style model and Carver and Scheirer's self-regulatory model are two theoretical models that have been used to define optimism (Peterson, 2000) [20]. According to Masten \& Reed (2002) [12], lot of theory and research on resilience have been taken from clinical psychology based on the studies of adolescent children who have bounced back from major difficulties. In general, it can be defined as an adaptive system which enables an individual to rebound or bounce back quickly from a setback or failure. In positive psychology, resilience is a positive adaptation process that can rebound in the context of significant adversity or risk (Masten \& Reed, 2002) [12]. As adapted to the work place, Luthans (2002) [10] defined resilience as "the positive psychological capacity to rebound, to 'bounce back' from adversity, uncertainty, conflict, failure, or even positive change, progress, and increased responsibility.” Based on this definition, it can be concluded that resilience is a positive strength that can be used to face adverse events as well as extreme positive events.

\subsection{Job Performance}

JP is the most extensively researched criterion variable in OB and the HRM literature (Borman et al., 1995) [21]. It is an important construct in industrial and organizational psychology. According to Murphy (1989) [22] performance definitions should focus on behaviors rather than outcomes, because if the managers focus only the employees' outcomes, employees will find the easiest way to achieve the outcomes without considering other important behaviors. Campbell et al., (1993) [23] explain that performance consists of the behaviors that employees actually engage in which can be observed. According to Moorhead and Griffin (1999) [24], JP is all of the total set of work related behaviors that the organization expects from the individuals to display. Motowidlo, Borman and Schmit (1997) [25] defined JP as behaviors or activities that are oriented towards the organization's goals and objectives. Similarly, Campbell, McHenry, \& Wise (1990) [26] defined JP as the observable behaviors that people do in their jobs that are relevant to the goals of the organization. Motowidlo, Borman, and Schmit (1997) [25] pointed out performance as behaviors with an evaluative aspect. It should be the behaviors relevant to the goals of the organization (Campbell et al., 1993) [23].

Traditionally, JP was evaluated in terms of the proficiency with which as individual carried out the tasks that were specified in their job description. Borman \& Motowidlo (1993) [27] supported this idea and stated that traditionally performance has been conceptualized in terms of the execution and completion of well-defined task. However, the changing nature of work and organizations has challenged the traditional view of JP. In review of the literature on JP, in mid-1990, Borman and Motowidlo (1993) [27] have identified two classifications that can 
be explored the JP. The central difference between these two classifications is in role performance and extra role performance. In role performance is the behavior that is directly correlated with the job tasks or requirements and extra role performance is the behavior that is not directly correlated with job task or requirements, but correlated with organizational outcomes. Borman and Motowidlo (1993) [27] defined in role performance as task performance and extra role performance as contextual performance.

\subsection{Work Attitudes}

Work attitudes are an individual's general attitude towards his or her job and the organization. Work attitudes can be defined as an employee's-evaluation and opinions of their jobs and their commitment to the organization (Verquer, Beehr, \& Wagner, 2003 as cited in Aarons \& Sawitzky, 2006 [28]). The majority of the researchers have found JS and OC as two important work attitudes in the organization. Robbins (2003) [4] defined JS as a subjective measure of worker attitudes, that is, an individual's general attitudes to his or her job. An employee with high JS holds positive attitudes towards their job and an employee with high job dissatisfaction holds negative attitudes towards his or her job. Ivancevich and Mattson (2005) [29] explained JS as an attitude that individuals have towards their jobs which stems from their perception of their jobs and the degree to which there is a good fit between the individual and the organization. Robbins \& Judge (2007) [30] defined JS as a positive feeling about one's job resulting from an evaluation of its characteristics. They further explained that employees that have high levels of JS hold positive feeling about their job, while dissatisfied employees hold negative feeling about their job. George and Jones (1996) [31] defined it as "the collection of feeling and beliefs that people have about their current jobs. Spector (1997) [32] defined JS as how employees feel about their overall job and various dimensions of their jobs. Work itself, pay, promotion, supervision, coworker, working condition are the mostly accepted dimensions of JS. According to Poter et al., (1974) [33] OC refers to the psychological attachment or affective commitment formed by an employee in relation to his/her identification and involvement with the respective organization. Moreover, they define it as "an attachment to the organization, characterized by intention to remain in it, identification with the values and goals of the organization, and a willingness to exert extra effort on its behalf." It is considered to be the linkage between the individual employee and the organization because of individuals consider the extent to which their own values and goals related to that of the organization as part of OC.

\subsection{PsyCap, Work Attitudes and Job Performance}

Luthans (2002) [9] emphasized that if any concept to consider as a positive psychological construct, it should be helped to improve the performance. Luthans and his colleagues stressed the ability of PsyCap to improve the performance. Lots of researches have examined the contribution of each construct of PsyCap on employee performance. Bandura (1997) [11] named self-confidence employees as good performers. According to his explanation, if the employees have high self-efficacy, they believe they can succeed. As a result they put more effort on the given task. When employees try harder to succeed, they generally perform better. It means that self-efficacy correlates with JP. According to Multiple meta-analyses self-efficacy has positively and strongly correlated with JP (Stajkovic \& Luthans, 1998 [13]; Bandura, 2000 [34]; Bandura \& Locke, 2003 [35]). Luthans, Avolio, Walumbwa, \& Li, (2005) [36] found that a relationship between Chinese factory workers' hope and supervisory rated performance. Similarly, hope has been found as a positive predictor of JP in different researches in different context (Luthans et al., 2005 [36]; Peterson \& Luthans, 2003 [37]; Youssef \& Luthans, 2007 [38]). Adams et al., (2002) [39] found that hopeful employees are more effective than the low hopeful employees. According to Bandura (1997) [11] self-efficacious and hopeful employees perform better because these employees accept challenges and put more efforts to achieve goals owing to their high efficacy. And also they identify sub goals and strategies to achieve those goals. According to Corr \& Gray (1996) [40] optimism has positively correlated with JP because when the employees believe that they can succeed, they are less likely to give up the task and put forth more effort to accomplish the goal. Seligman (1998) [41] found that positive relationship between optimism and JP among the insurance sales agents. Luthans et al., (2005) [36] found similar result in Chinese factory workers. Youssef and Luthans (2007) [38] reported positive relationship between optimism and employees performance. Maddi (2005) [42] stated that the important of this psychological capacity (resilience) in enhancing the performance of the employees in the turbulent environment. According to Seligman (1998) optimism is positively and significantly correlated with JP of insurance sales agents. Similar result was found by Youssef 
and Luthans (2007) [38]. Luthan et al., (2005) [36] found that significant relationship between resilience and rated performance of the Chinese workers. The composite effect of PsyCap as a multi-dimen- sional construct may be significantly and positively correlated on JP. Avey \& Nimnicht (2009) [43] found that PsyCap (self-efficacy, hope, optimism and resilience) is positively correlated with managers' evaluations of employee performance in the two field studies. Some researchers have found similar results (Avey \& Nimnicht, 2010 [43]; Luthans et al., 2007 [8]). Stajkovic (2006) [44] pointed out the importance of combined effect of four facets of PsyCap to improve performance. Fredrickson (2001) [45] suggested that "higher levels of positivity will contribute to maintaining higher levels of individual motivation and performance".

For the purpose of this study work attitudes defined as an individual's general attitude towards his or her job and the organization. JS and OC were considered as two dimensions of work attitudes. According to the empirical evidence, PsyCap has positively correlated with JS and the correlation between PsyCap and JS is stronger than correlation between the individual construct of PsyCap and JS. Appollis (2010) [46] stressed that the relationship between PsyCap and JS is strong and linear among the employees who worked in the tourism sector. Further, this finding indicates highly self-confidence, hopeful, optimistic and resilient employees have high level of JS. According to a research done by Larson \& Luthans (2006) [47] in production workers who worked in small Midwestern factory, they found that hopeful production workers were more satisfied with their jobs. A similar result was found by Youssef \& Luthans in 2007 [38]. They found that employees' level of hope was correlated with JS. Peterson \& Luthans (2003) have confirmed this relationship and stressed that hopeful managers who worked in the fast food stores have showed more satisfaction [37]. In general, the employees' higher level of hope will lead to the improvement of their JS because the hope level of employees enable them to self-motivate and plan their activities so as to gain best of their situation (Youssef \& Luthans, 2007) [38]. Anyway, researchers have pointed out the higher level of JS can be found when the hope is accompanied by the level of self-efficacy and optimism of the employees and the ability that they can respond favorably to setbacks. Youssef and Luthans (2007) [38] and Cetin (2011) [48] found that hopeful, optimistic and resilience employees are more satisfied with their jobs. Larson \& Luthans (2006) with their exploratory study in small factory found that positive relationship between the level of PsyCap of production worker and their JS [47]. Luthans et al., (2007) [7] did a research taking two samples of management students, technicians and engineers. It revealed positive relationship between PsyCap and JS. The relationship between PsyCap and JS was stronger than the relationship between each construct of PsyCap and JS. Luthans et al., (2008) [49] found similar result and stressed that there was a positive relationship between general PsyCap and JS.

To date there are very few studies that have explored the relationship between PsyCap and OC. Among them, Luthans, Avolio, Walumbwa, \& Li, (2004) [36] found that PsyCap is positively related to OC. Similar to this finding, Youssef \& Luthans (2007) [38] found that the four construct of PsyCap (self-efficacy, hope, optimism and resiliency) have correlated with OC. Again, Luthans with Bruce, Avolio \& Avey, (2008) [49] confirmed the ability of PsyCap to influence the OC. Shahnawaz \& Jafri (2009) [50] have done a research using public and private organizations in India and found that slight positive relationship between PsyCap and OC among the managers. Sinha, Talwar, and Rajpal (2002) [51] stated that there was a positive relationship between self- efficacy and OC in a sample of 167 managers. Larson \& Luthans (2006) with their exploratory study in small factory found that positive relationship between the level of PsyCap of production worker and their OC [47]. A similar result was found by Youssef \& Luthans, (2007) [38]. Cetin (2011) [48] found a positive relationship between three construct of PsyCap (hope, optimism and resilience) and OC.

Wei and Chu (2008) [52] found that a work attitude has a positive relationship with JP with their survey conducted on employees in the financial service industry. Kappagoda (2013) [53] found similar results from Sri Lankan banking sector. According to his research, he found a significant positive relationship between work attitudes and JP. Work attitudes have significantly explained 35.9\% of the variance in the JP of the non-managerial employees in the banking sector.The relationship between JS and JP has received much attention from the Human Relations movement in 1930s. Overall JS and JP (Birnbaum and Somers, 1993 [54]; Dart, 1988 [55]; Igbaria, 1991 [56]; Meyer et al., 1989 [57]; Shore and Martin, 1989 [58]) as well as multi faced JS and JP have re- ceived significant attention in the past research. Herzberg, Mausner, and Snyderman (1959) [59] believed that productivity will be increased with the improvement of the moral of the employees. However, Lawler \& Porter (1967) [60] explored that the high performed employees were more satisfied employees because they received greater rewards. In the 1985s, this relationship was reversed and found that more satisfied employees are better performers. According to "happy-productive worker hypothesis" (Kluger \& Tikochinsky, 2001 [61]; Staw 
\& Barsade, 1993) [62], people believed that happy employees are more satisfy with their jobs and it will help to perform better on their jobs. According to Iaffaldano \& Muchinsky, (1985) [63] research has reported a positive correlation between individuals' JS and their performance. However they concluded that satisfaction and performance are slightly related. In this connection, they used facet level of JS. JS of the employees may be a better predictor of JP (Judge, Thoresen, Bono, \& Patton, 2001) [64]. Once again, Judge, Thoresen, Bono, \& Patton, (2001) found much stronger positive correlation between JS and individual performance in the more recent meta-analysis [64]. They used global level of JS. Moshavi \& Terborg (2002) [65] revealed a positive relationship between JS and JP among the sample of contingent and regular customer service representatives. Spector (1997) [32] suggested a potential relationship between satisfaction and performance.

Several researchers have focused their studies on the relationship between OC and JP (Porter et al., 1974) [33]. According to empirical evidence it has been given mixed results. The results have been mixed (Becker, Billings, Eveleth, \& Gilbert, 1996) [66]. OC has positively correlated with JP of the industrial salespeople (Meyer et al., 1989 [57]). Vinchur et al., (1998) [67] explored similar result and said that OC is one of the variables that influence on JP. In addition, Morrow (1993) [68] pointed out that high committed employee as high performing employees. Jaramillo et al., (2005) [69] found a positive correlation between OC and JP with the result of metaanalysis which was conducted using 51 empirical studies. Chen, Silverthrone and Hung (2006) [70] found a positive correlation between OC and JP among accounting professionals. Mathieu \& Zajac (1990) [71] found weak positive relationship between OC and JP but they pointed out a tendency of high commitment of the employees to perform well. Other researchers have identified insignificance or negative relationship between two variables (Leong et al., 1994) [72]. This different result can be predicted owing to different conceptualization of commitment. Rashid, Sambasvani and Joari (2003) [73] examined 202 managers in Malaysian companies and they found that corporate culture and OC are correlated on the performance. Lots of researches have typically focused on affective commitment and JP relationship. Affective commitment was the most significant predictor of individual performance (Brett et al., 1995) [74]. According to Allen and Meyer (1996) there was a positive relationship between affective commitment and JP [75]. Similar result was found by some other researchers (Luchak \& Gellatly, 2007 [76]; Meyer et al., 1989 [57]). Affectively committed employees performed better than those who are not (Meyer et al., 1989 [57]). Affective commitment has been positively correlated with supervisor ratings of JP among laboratory technicians (Konovsky \& Cropanzano, 1991) [77]. Similar result was found among the first-level managers in food service (Meyer et al., 1989) [57] and employees from various levels and positions (Mayer \& Schoorman, 1992) [78]. In generally, it can be predicted a positive correlation between OC and JP because committed employees are happy to be members of the organization. They have positive attitude about the organization. Thus, they intend to give best for the organization so as to achieve the goals of the organization. As a result, JP can be increased. Based on these empirical evidences, the following hypotheses are formulated.

H1: There is a positive relationship between PsyCap and job performance of the employees in the banking sector in Sri Lanka.

H2: There is a positive relationship between PsyCap and work attitudes of the employees in the banking sector in Sri Lanka.

H3: There is a positive relationship between work attitudes and job performance of the employees in the banking sector in Sri Lanka.

H4: Work attitudes mediate the relationship between PsyCap and job performance of the employees in the banking sector in Sri Lanka.

\section{Research Methodology}

\subsection{Research Design}

The current study employed a correlational research design in order to explore the relationship between PsyCap (independent variable) and JP (dependent variable).Work attitudes is the mediating variable. This field study is conducted in natural environment in banking sector under non-contrived settings. The unit of study is individual.

\subsection{Population and Sample}

The population of this study was consisted of managers and non-managerial employees in the banking sector in 
Sri Lanka. The sample for this study was initially derived by randomly selected 220 managers and 440 nonmanagerial employees who employed in banking sector in Sri Lanka throughout the seven provinces. The response rate was $81 \%$.

\subsection{The Sampling Method}

Firstly, The Systemically Important Banks (SIBs) and Systemically Important Specialized Banks (SISBs) were selected because of their high performance and they possess large proportion of assets of the banking sector. Then, 10\% branches from SIBs and SISBs in seven provinces were selected using a convenient sampling method. Finally, an assistant manager and two non-managerial employees were selected from each branch with the consultation of the branch manager.

\subsection{Measures}

The managers and non-managerial employees’ JP was the dependent variable and PsyCap of the managers and non-managerial employees was the independent variable of this research. The work attitudes are the mediating variable. These variables were measured using standard instruments. The questionnaire was separated into four sections for demographic data, PsyCap, JP and work attitudes. Seven questions were included to get the demographic information. The employees' PsyCap was measured by standard questionnaire which was originally developed by Luthans and colleagues (2007) [8]. It was consisted of 24 questions and included 6 items for each of the four components of hope, efficacy, resilience and optimism. JP intends to measure self-rated and supervisor rated JP. Self-rated \& supervisor rated JP was measured using two dimensions (task performance, contextual performance) and 21 questions. Work attitudes were measured using two dimensions (JS and affective commitment) and 19 questions (details in Appendix 1).

\subsection{Validity and Reliability}

Luthans, et al., (2007) [8] have constructed PsyCap questionnaire including 24 questions. According to them, they have appointed an expert panel to select items for each four construct of PsyCap (self-efficacy, hope, optimism and resilience). The panel has selected six items for each of the four construct so as to secure the content and face validity. They have adapted wordings to match with workplace. This questionnaire was validated by using the confirmatory factor analysis across multiple samples (Luthans, Avolio, Avey, \& Norman, 2007) [8]. However, three items of this instrument were dropped owing to lack convergent validity.

Task performance and contextual performance were used to measure JP. Task performance instrument developed by Borman, Ackerman and Kubisiak’s (1995) [21] and contextual performance questionnaire developed by Motowidlo and Van Scotter (1994) [79] were used in this study. Task Performance was measured using three sub dimensions (task proficiency, efficiency and problem solving). This instrument includes 08 questions. Contextual performance was measured using five sub dimensions (volunteering to carry out task activities, persisting with extra efforts, helping and cooperating with others, following organizational rules and procedures, endorsing, supporting organizational procedures) and the instrument includes 13 items.

Work attitude was measured using JS and affective commitment. JS was measured using 6 sub dimensions (work itself, pay, promotion, supervision, coworkers, working condition) and 12 questions. Affective commitment was measured using 8 questions developed by Allen and Meyer in 1990 [80]. It has three dimensions called emotional attachment, identification of the organizations, and involvement. Seven questions were included in the final instrument.

Table 1 shows the Cronbach coefficient alpha for each instrument. According to the data, it can be concluded that the instruments possesses high reliability owing to the data.

\subsection{Methods of Data Analysis}

The data analysis included univariate, bivariate and multivariate analyses. Collected data were analyzed using the SPSS data analysis package. For the purpose of investigating the mediating effect, the three steps which were recommended by Baron and Kenny in 1986 [81] were used. According to these authors, as the first, the mediator should be predicted by the independent variable. The dependent variable should be predicted by the mediator and the independent variable as the second step. Finally, the dependent variable should be regressed on 
the independent variable, controlling for the mediator.

\section{Results}

According to the data in Table 2, the level of PsyCap, JP and work attitudes are in high level among the employees.

The data of Table 2 represented the correlation coefficient of each variable. A significant positive relationship can be seen between PsyCap and work attitudes $(r=0.514)$. The same results have been reported between PsyCap and job performance $(r=0.481)$ and work attitudes and job performance $(r=0.377)$. Table 3 showed the results of the regression analysis. According to the data of tables, PsyCap and work attitudes have significantly and positively correlated to JP whereas PsyCap has also significantly and positively correlated to work attitudes. Based on the results on correlational coefficient and regression analysis, hypotheses one, two and three can be accepted.

According to the results of Table 4, the introduction of work attitudes in the analysis reduces the impact of PsyCap. The $\beta$ has dropped from $0.481(\mathrm{P}<0.01)$ in step 01 to $0.390(\mathrm{P}<0.01)$ in step 02 .

Table 1. Cronbach coefficient alpha values.

\begin{tabular}{cc}
\hline Variables & Alpha value \\
\hline PsyCap & 0.921 \\
Job performance & 0.926 \\
Work attitudes & 0.900 \\
\hline
\end{tabular}

Table 2. Means, standard deviation and correlations.

\begin{tabular}{ccccc}
\hline Variables & Mean & Standard Deviation & $\mathbf{1}$ & - \\
1. PsyCap & 3.86 & 0.391 & $0.514^{* *}$ \\
2. Work attitudes & 3.87 & 0.457 & - & $0.481^{* *}$ \\
3. Job Performance & 3.95 & 0.328 & $0.377^{* *}$ \\
\hline
\end{tabular}

${ }^{* *} \mathrm{p}<0.01$

Table 3. Results of simple regression analysis.

\begin{tabular}{rrrrr}
\hline & $\boldsymbol{\beta}$ & R Square & F value & P value \\
\hline Predictors: (Constant), PsyCap Dependent Variable: Job Performance & 0.481 & 0.231 & 159.65 & 0.00 \\
Predictors: (Constant), PsyCap Dependent Variable: Work Attitudes & 0.514 & 0.264 & 190.63 & 0.00 \\
Predictors: (Constant), Work Attitudes Dependent Variable: Job Performance & 0.377 & 0.142 & 87.80 \\
\hline
\end{tabular}

Table 4. Results of hierarchical regression.

\begin{tabular}{ccc}
\hline & & Job Performance \\
\hline PsyCap $\beta$ & Step 01 & 02 \\
Work attitudes $\beta$ & $0.481^{* *}$ & $0.390^{* *}$ \\
$\mathrm{R}$ & - & $0.176^{* *}$ \\
$\mathrm{R}^{2}$ & 0.481 & 0.504 \\
F value & 0.231 & 0.254 \\
9
\end{tabular}

\footnotetext{
${ }^{* *} \mathrm{p}<0.01$
} 


\section{Discussion}

The main objectives of this study were to investigate the mediating effect of work attitudes on the relationship between PsyCap and JP and to identify the relationships among PsyCap, work attitudes and JP of the employees in the banking sector in Sri Lanka. For this purpose, four hypotheses were formulated.

The results of correlation coefficient and regression analysis indicated that PsyCap of employees has significantly and positively correlated to their JP. Therefore, the hypothesis one can be accepted according to the statistical evidence. The PsyCap has significantly explained 23.1\% of variance in JP. All the dimensions of PsyCap have significantly and positively correlated with JP. The researcher evaluated the employees' JP using self-rated performance and supervisory rated performance to get a better picture regarding the employees' JP. Ultimately, JP was evaluated using the average of self-rated and supervisory rated JP. Supervisory rated JP was somewhat low comparing with self-rated JP. However PsyCap has positively correlated with both self-rated and supervisory rated JP. The result of this study was generally consistent with previous studies. Luthans and his colleagues (2002a) [9] stressed the ability of PsyCap to improve the performance. The results of this research confirmed the findings of Luthans. Some researchers (Stajkovic \& Luthans, 1998 [13]; Bandura, 2000 [34]; Bandura \& Locke, 2003 [35]; Snyder, 2000 [15]; Luthans, Avolio, Walumbwa, \& Li, 2005 [36]; Corr \& Gray, 1996 [40]) have found positive relationships between each construct of PsyCap and JP. The findings of this research also agreed on the previous findings.

A positive relationship between PsyCap and work attitudes was predicted as the second hypothesis. The data shows that the relationship between PsyCap and work attitudes of the employees in the banking sector has significantly and positively correlated. The results indicate that the employees who have high PsyCap are likely to be satisfied and committed to their jobs. PsyCap of employees has significantly explained $26.4 \%$ of variance of their job work attitudes. There was a significant linear relationship between PsyCap and work attitudes ( $\mathrm{F}=$ 190.63). The result of this research was consistent with the studies of Luthans et al., (2007); Larson and Luthans (2006) [47].

There is statistical evidence to accept the third hypothesis which was formulated in this study. The work attitudes of the employees have significantly and positively correlated with JP. It means that the employees who are highly satisfied and committed are high performers in the banking sector. It has significantly explained $14.2 \%$ of the variance in JP.

Furthermore, the researcher formulated a hypothesis to investigate the mediating effect of work attitudes on the relationship between PsyCap and JP. For this purpose, the three steps which were recommended by Baron and Kenny in 1986 were used. The result of Table 2 and Table 3 indicated the ability of PsyCap to predict the work attitudes. The results in Table 2 and Table 3 showed that JP can be predicted by PsyCap and work attitudes. The data suggested that there is an evidence to prove the first and second steps of Baron and Kenny's procedure. According to the results of Table 4, the introduction of work attitudes in the analysis reduced the impact of PsyCap. The $\beta$ has dropped from $0.481(\mathrm{P}<0.01)$ in step 01 to $0.390(\mathrm{P}<0.01)$ in step 02. Both PsyCap $(\beta=0.390, \mathrm{P}<0.01)$ and work attitudes $(\beta=0.176, \mathrm{P}<0.01)$ remains a significant predictors in the last analysis. Therefore, according to Baron and Kenny (1986), it can be assumed that there is a partial mediation in this case. Thus, the final hypothesis can be accepted.

\section{Limitations and Directions for Further Results}

The results must be considered with several limitations. The data collection was confined to systemically important banks and systemically important specialized banks is the first limitation of this research study. Second limitation was of relying on self-reported data. The PsyCap, work attitudes of the employees were measured according to the respondents' own attitudes.

The present study has been provided many potential paths for future researchers. In this study PsyCap, work attitudes and JP were the major variables of interest. The research study attempted to demonstrate the mediating effect of work attitudes. The further researches would be advantages to explore potential mediators except work attitudes and moderators for the relationship between PsyCap and JP. This research focused only the systemically important banks and systemically important specialized banks but other researchers can expand the sample to the other banks, service organizations or different organizations in Sri Lanka.

\section{Conclusion}

Based on the results of the study, it can be concluded that there is a partial mediating effect of work attitudes of 
the employees on the relationship between PsyCap and JP of the employees. In addition to that, the correlation between PsyCap and JP, PsyCap and work attitudes, work attitudes and JP are significant and positive. Understanding these relationships will be helpful to the strategists in the banking sector when they are formulating strategies regarding their human resources.

\section{References}

[1] Karatepe, O.M. and Tekinkus, M. (2006) The Effects of Work-Family Conflict, Emotional Exhaustion, and Intrinsic Motivation on Job Outcomes of Front-Line Employees. International Journal of Bank Marketing, 24, 173-193.

[2] Gabbott, M. and Hogg, G. (1997) Contemporary Services Marketing Management. The Dryden Press.

[3] Luthans, F., Luthans, K.W. and Luthans, B.C. (2004) Positive Psychological Capital: Beyond Human and Social Capital. Business Horizons, 47, 45-50. http://dx.doi.org/10.1016/j.bushor.2003.11.007

[4] Robbins, P.S. (2003) Organizational Behaviour: Concepts, Controversies, and Applications. 5th Edition, Prentice Hall International, Inc., London.

[5] Porter, L.W., Steers, R.M., Mowday, R.T. and Boulian, P.V. (1974) Organizational Commitment, Job Satisfaction, and Turnover among Psychiatric Technicians. Journal of Applied Psychology, 59, 603-609. http://dx.doi.org/10.1037/h0037335

[6] Chughtai, A.A. and Zafar, S. (2006) Antecedents and Consequences of Organizational Commitment among Pakistani University Teachers. Applied Human Resource Management Research, 11, 39-64.

[7] Avey, J.B., Reichard, R.J., Luthans, F. and Mhatre, K.H. (2011) Meta-Analysis of the Impact of Positive Psychological Capital on Employee Attitudes, Behaviors, and Performance. Human Resource Development Quarterly, 22, 127-152. http://dx.doi.org/10.1002/hrdq.20070

[8] Luthans, F., Avolio, B.J., Avey, J.B. and Norman, S.M. (2007) Positive Psychological Capital: Measurement and Relationship with Performance and Satisfaction. Personnel Psychology, 60, 541-572. http://dx.doi.org/10.1111/j.1744-6570.2007.00083.x

[9] Luthans, F. (2002) Positive Organizational Behavior: Developing and Managing Psychological Strengths. Academy of Management Executive, 16, 57-75. http://dx.doi.org/10.5465/AME.2002.6640181

[10] Luthans, F. (2002) The Need for and Meaning of Positive Organizational Behavior. Journal of Organizational Behavior, 23, 695-706. http://dx.doi.org/10.1002/job.165

[11] Bandura, A. (1997) Self-Efficacy: The Exercise of Control. Freeman, New York.

[12] Masten, A.S. and Reed, M.G. (2002) Resilience in Development. In: Snyder, C.R. and Lopez, S.J., Eds., The Handbook of Positive Psychology, Oxford University Press, New York, 74-88.

[13] Stajkovic, A.D. and Luthans, F. (1998) Self-Efficacy and Work-Related Performance: A Meta-Analysis. Psychological Bulletin, 124, 240-261. http://dx.doi.org/10.1037/0033-2909.124.2.240

[14] Snyder, C.R., Harris, C., Anderson, J.R., Holleran, S.A., Irving, L.M., Sigmon, S.T., et al. (1991) The Will and the Ways: Development and Validation of an Individual-Differences Measure of Hope. Journal of Personality and Social Psychology, 60, 570-585. http://dx.doi.org/10.1037/0022-3514.60.4.570

[15] Snyder, C.R. (2000) The Past and Possible Futures of Hope. Journal of Social and Clinical Psychology, 19, 11-28. http://dx.doi.org/10.1521/jscp.2000.19.1.11

[16] Snyder, N.F.R., Derrickson, S.C., Beissinger, S.R., Wiley, J.W., Smith, T.B., Toone, W.D. and Miller, B. (1996) Limitations of Captive Breeding in Endangered Species Recovery. Conservation Biology, 10, 338-348. http://dx.doi.org/10.1046/j.1523-1739.1996.10020338.x

[17] Snyder, C.R. (1996) To Hope, to Lose, and Hope Again. Journal of Personal and Interpersonal Loss, 1, 1-16.

[18] Carver, C.S., Smith, R.G., Antoni, M.H., Petronis, V.M., Weiss, S. and Derhagopian, R.P. (2005) Optimistic Personality and Psychosocial Well-Being during Treatment Predict Psychosocial Well-Being among Long-Term Survivors of Breast Cancer. Health Psychology, 24, 508-516. http://dx.doi.org/10.1037/0278-6133.24.5.508

[19] Tiger, L. (1979) Optimism: The Biology of Hope. Simon \& Schuster, New York.

[20] Peterson, C. (2000) The Future of Optimism. American Psychologist, 55, 44-55. http://dx.doi.org/10.1037/0003-066X.55.1.44

[21] Borman, W.C., Ackerman, L.D. and Kubisiak, U.C. (1995) Development of a Performance Rating Program in Support of Department of Labor Test Validation Research. Cooperative Personnel Services, Sacremento.

[22] Murphy, K.R. (1989) Dimensions of Job Performance. In: Dillon, R. and Pellingrino, J., Eds., Testing: Applied and Theoretical Perspectives, Praeger, New York, 218-247.

[23] Campbell, J.P., McCloy, R.A., Oppler, S.H. and Sager, C.E. (1993) A Theory of Performance. In: Schmitt, N. and Bor- 
man, W.C., Eds., Personnel Selection in Organizations, Jossey-Bass Publishers, San Francisco, 35-70.

[24] Moorhead, G. and Griffin, R.W. (1999) Organizational Behaviour: Managing People and Organization. 3rd Edition, Jaico Publishing House, Mumbai.

[25] Motowidlo, S.J., Borman, W.C. and Schmit, M.J. (1997) A Theory of Individual Differences in Task and Contextual Performance. Human Performance, 10, 71-83. http://dx.doi.org/10.1207/s15327043hup1002_1

[26] Campbell, J.P., McHenry, J.J. and Wise, L.L. (1990) Modeling Job Performance in a Population of Jobs. Personnel Psychology, 43, 313-575. http://dx.doi.org/10.1111/j.1744-6570.1990.tb01561.x

[27] Borman, W.C. and Motowidlo, S.J. (1993) Expanding the Criterion Domain to Include Elements of Contextual Performance. In: Schmitt, N. and Borman, W.C., Eds., Personnel Selection in Organizations, Jossey-Bass, San Francisco, 7198.

[28] Aarons, G.A. and Sawitzky, A.C. (2006) Organizational Climate Partially Mediates the Effect of Culture on Work Attitudes and Staff Turnover in Mental Health Services. Administration and Policy in Mental Health and Mental Health Services Research, 33, 289-301. http://dx.doi.org/10.1007/s10488-006-0039-1

[29] Ivancevich, J.M., Matteson, M.T. and Richards, E.P. (2005) Who’s Liable for Stress at Work? Harvard Business Review, 63, 60-72.

[30] Robbins, S.P. and Judge, T.A. (2007) Organizational Behavior. 12th Edition, Prentice Hall, Upper Saddle River.

[31] George, J.M. and Jones, G.R. (1996) Understanding and Managing Organizational Behavior. Addison-Wesley, Reading.

[32] Spector, P. (1997) Job Satisfaction: Application, Assessment, Causes and Consequences. Sage, Thousand Oaks. http://dx.doi.org/10.4135/9781452231549

[33] Porter, L., Mowday, R. and Dubin, R. (1974) Unit Performance, Situational Factors and Employee Attitudes in Spatially Separate Work Units. Organizational Behaviors and Human Performance, 12, 231-248. http://dx.doi.org/10.1016/0030-5073(74)90048-8

[34] Bandura, A. (2000) Cultivate Self-Efficacy for Personal and Organizational Effectiveness. In: Locke, E., Ed., The Blackwell Handbook of Principles of Organizational Behavior, Blackwell, Oxford, 120-136.

[35] Bandura, A., and Locke, E. (2003) Negative Self-Efficacy and Goal Effects Revisited. Journal of Applied Psychology, 88, 87-99. http://dx.doi.org/10.1037/0021-9010.88.1.87

[36] Luthans, F., Avolio, B.J., Walumbwa, F.O. and Li, W. (2005) The Psychological Capital of Chinese Workers: Exploring the Relationship with Performance. Managerial and Organization Review, 1, 247-269. http://dx.doi.org/10.1111/j.1740-8784.2005.00011.x

[37] Peterson, S.J. and Luthans, F. (2003) The Positive Impact and Development of Hopeful Leaders. Leadership \& Organization Development Journal, 24, 26-31. http://dx.doi.org/10.1108/01437730310457302

[38] Youssef, C.M. and Luthans, F. (2005) Resilience Development of Organizations, Leaders and Employees: Multi-Level Theory Building for Sustained Performance. In: Gardner, W., Avolio, B. and Walumbwa F., Eds., Authentic Leadership Theory and Practice: Origins, Effects and Development, Elsevier, Oxford, 303-343.

[39] Adams, V.H., Snyder, C.R., Rand, K.L., King, E.A., Sigman, D.R. and Pulvers, K.M. (2002) Hope in the Workplace. In: Giacolone, R. and Jurkiewicz, C., Eds., Handbook of Workplace Spirituality and Organization Performance, Sharpe, New York, 367-377.

[40] Corr, P.J. and Gray. J.A. (1996) Attributional Style as a Personality Factor in Insurance Sales Performance in the UK. Journal of Occupational and Organizational Psychology, 69, 83-87. http://dx.doi.org/10.1111/j.2044-8325.1996.tb00601.x

[41] Seligman, M. (1998) Learned Optimism. New York, NY: Pocket Books. Wunderley, L.J., Reddy, W.P. and Dember, W.N., Optimism and Pessimism in Business Leaders. Journal of Applied Social Psychology, 28, 751-760.

[42] Maddi, S.R. (2005) On Hardiness and Other Pathways to Resilience. American Psychology, 60, 261-262. http://dx.doi.org/10.1037/0003-066X.60.3.261

[43] Avey, J.B., Nimnicht, J.L. and Graber Pigeon, N. (2010) Two Field Studies Examining the Association between Positive Psychological Capital and Employee Performance. Leadership \& Organization Development Journal, 31, 384401.

[44] Stajkovic, A.D. (2006) Development of a Core Confidence-Higher Order Construct. Journal of Applied Psychology, 91, 1208-1224. http://dx.doi.org/10.1037/0021-9010.91.6.1208

[45] Fredrickson, B.L. (2001) The Role of Positive Emotions in Positive Psychology, the Broaden-and-Build Theory of Positive Emotions. American Psychologist, 56, 218-226. http://dx.doi.org/10.1037/0003-066X.56.3.218

[46] Appollis, V.P. (2010) The Relationship between Intention to Quit, Psychological Capital and Job Satisfaction in the 
Tourism Industry in the Western Cape. Unpublished Dissertation, University of the Western Cape, Cape Town.

[47] Larson, M. and Luthans, F. (2006) Potential Added Value of Psychological Capital in Predicting Work Attitudes. Journal of Leadership and Organization Studies, 13, 44-61. http://dx.doi.org/10.1177/10717919070130020601

[48] Cetin, F. (2011) The Effects of the Organizational Psychological Capital on the Attitudes of Commitment and Satisfaction: A Public Sample in Turkey. European Journal of Social Sciences, 21, 373-380.

[49] Luthans, F., Norman, S.M., Avolio, B.J. and Avey, J.B. (2008) The Mediating Role of Psychological Capital in the Supportive Organizational Climate: Employee Performance Relationship. Journal of Organizational Behavior, 29, 219238. http://dx.doi.org/10.1002/job.507

[50] Shahnawas, M.G. and Jafri, H. (2009) Job Attitudes Are Predictor of Employee Turnover among Stayers and Leavers, Journal of Management Research, 9, 156-159.

[51] Sinha, S.P., Talwar, T. and Rajpal, R. (2002) Correlational Study of Organizational Commitment, Self-Efficacy and Psychological Barriers to Technological Change. Psychology, 45, 176-183. http://dx.doi.org/10.2117/psysoc.2002.176

[52] Wei, W.C. and Chu, S.H. (2008) Empirical Study on the Correlation among Personality Traits, Work Attitudes, Service Quality, Job Performances and Customers' Satisfaction-A Financial Holding Company in Taiwan. International Journal of Lisrel, 1, 1-24.

[53] Kappagoda, S. (2013) The Impact of Work Related Attitudes on Job Performance of Non-Managerial Employees in the Banking Sector in Sri Lanka, Zenith. International Journal of Multidisciplinary Research, 3, 1-7.

[54] Birnbaum, D. and Somers, M.J. (1993) Fitting Job Performance into Turnover Model: An Examination of the Form of the Job Performance-Turnover Relationship and Path Model. Journal of Management, 49, 1-11. http://dx.doi.org/10.1177/014920639301900101

[55] Dart, J. (1988) Job Satisfaction among Canadian Shopping Center Managers. International Journal of Retailing, 3, 2234.

[56] Igbaria, M. (1991) Job Performance of MIS Professionals: An Examination of the Antecedents and Consequences. Journal of Engineering \& Technology Management, 8, 141-171. http://dx.doi.org/10.1016/0923-4748(91)90027-O

[57] Meyer, J.P., Paunonen, S.V., Gellatly, I.R., Goffin, R.D. and Jackson, D.N. (1989) Organizational Commitment and Job Performance: It’s the Nature of the Commitment That Counts. Journal of Applied Psychology, 74, 152-156. http://dx.doi.org/10.1016/0923-4748(91)90027-O

[58] Shore, L.M. and Martin, H.J. (1989) Job Satisfaction and Organizational Commitment in Relation to Work Performance and Turnover Intentions. Human Relations, 42, 625-638. http://dx.doi.org/10.1177/001872678904200705

[59] Herzberg, F., Mausner, B. and Snyderman, B. (1959) The Motivation to Work. John Wiley \& Sons, New York.

[60] Lawler, E.E. and Poter, L.W. (1967) Antecedent Attitudes of Effective Managerial Performance. Organizational Behavior and Human Performance, 2, 122-142. http://dx.doi.org/10.1016/0030-5073(67)90026-8

[61] Kluger, A.N. and Tikochinsky, J. (2001) The Error of Accepting the “Theoretical” Null Hypothesis: The Rise, Fall, and Resurrection of Commonsense Hypotheses in Psychology. Psychological Bulletin, 127, 408-423. http://dx.doi.org/10.1037/0033-2909.127.3.408

[62] Staw, B.M. and Barsade, S.G. (1993) Affect and Managerial Performance: A Test of the Sadder-but-Wiser vs. Happier-and-Smarter Hypothesis. Administrative Science Quarterly, 38, 304-331. http://dx.doi.org/10.2307/2393415

[63] Iaffaldano, M.T. and Muchinsky, P.M. (1985) Job Satisfaction and Job Performance: A Meta-Analysis. Psychological Bulletin, 97, 251-273. http://dx.doi.org/10.1037/0033-2909.97.2.251

[64] Judge, T.A., Thoresen, C.J., Bono, J.E. and Patton, G.K. (2001) The Job Satisfaction—Job Performance Relationship: A Qualitative and Quantitative Review. Psychological Bulletin, 127, 376-407. http://dx.doi.org/10.1037/0033-2909.127.3.376

[65] Moshavi, D. and Terborg, J.R. (2002) The Job Satisfaction and Performance of Contingent and Regular Customer Service Representatives: A Human Capital Perspective. International Journal of Service Industry Management, 13, 333347. http://dx.doi.org/10.1108/09564230210445069

[66] Becker, T.E., Billings, R.S., Eveleth, D.M. and Gilbert, N.L. (1996) Foci and Bases of Employee Commitment: Implications for Job Performance. Academy of Management Journal, 39, 464-482. http://dx.doi.org/10.2307/256788

[67] Vinchur, A.J., Schippmann, J.S., Switzer, F.S. and Roth, P.L. (1998) A Meta-Analytic Review of Predictors of Job Performance for Salespeople. Journal of Applied Psychology, 83, 586-597. http://dx.doi.org/10.1037/0021-9010.83.4.586

[68] Morrow, P. (1993) The Theory and Measurement of Work Commitment. JAI Press, Greenwich.

[69] Jaramillo, F., Mulki, J.P. and Marshall, G.W. (2005) A Meta-Analysis of the Relationship between Organizational Commitment and Salespeople Job Performance: 25 Years of Research. Journal of Business Research, 58, 705-714. 
http://dx.doi.org/10.1016/j.jbusres.2003.10.004

[70] Chen, J.C., Silverthorne, C. and Hung, J.Y. (2006) Organization Communication, Job Stress, Organizational Commitment, and Job Performance of Accounting Professionals in Taiwan and America. Leadership \& Organization Development Journal, 27, 242-249. http://dx.doi.org/10.1108/01437730610666000

[71] Mathieu, J.E. and Zajac, D. (1990) A Review and Meta-Analysis of the Antecedents, Correlates, and Consequences of Organizational Commitment. Psychological Bulletin, 108, 171-194. http://dx.doi.org/10.1037/0033-2909.108.2.171

[72] Leong, S.M., Randoll, D.N. and Cote, J.A. (1994) Exploring the Organizational Commitment-Performance. Journal of Business Research, 29, 57-63. http://dx.doi.org/10.1016/0148-2963(94)90027-2

[73] Rashid, M.Z.A., Sambasivan, M. and Johari, J. (2003) The Influence of Corporate Culture and Organisational Commitment on Performance. Journal of Management Development, 22, 708-728. http://dx.doi.org/10.1108/02621710310487873

[74] Brett, J.P., Cron, W.L. and Slocum, J.W. (1995) Economic Dependence on Work: A Moderator of the Relationship between Organizational Commitment and Performance. Academy of Management Journal, 38, 261-271. http://dx.doi.org/10.2307/256735

[75] Allen, N.J. and Meyer, J.P. (1996) Affective, Continuance, and Normative Commitment to the Organization: An Examination of Construct Validity. Journal of Vocational Behavior, 49, 252-276. http://dx.doi.org/10.1006/jvbe.1996.0043

[76] Luchak, A. and Gellatly, I. (2007) A Comparison of Linear and Nonlinear Relations between Organizational Commitment and Work Outcomes. Journal of Applied Psychology, 92, 786-793. http://dx.doi.org/10.1037/0021-9010.92.3.786

[77] Konovsky, M.A. and Cropanzano, R. (1991) Perceived Fairness of Employee Drug Testing as a Predictor of Employee Attitudes and Job Performance. Journal of Applied Psychology, 76, 698-707. http://dx.doi.org/10.1037/0021-9010.76.5.698

[78] Mayer, R.C. and Schoorman, F.D. (1992) Predicting Participation and Production Outcomes through a Two-Dimensional Model of Organizational Commitment. Academy of Management Journal, 35, 671-684. http://dx.doi.org/10.2307/256492

[79] Motowidlo, S.J. and Van Scotter, J.R. (1994) Evidence That Task Performance Should Be Distinguished from Contextual Performance. Journal of Applied Psychology, 79, 475-480.

[80] Allen, N.J. and Meyer, J.P. (1990) The Measurements and Antecedent of Affective, Continuance and Normative Commitment to the Organization. Journal of Occupational Psychology, 63, 1-18. http://dx.doi.org/10.1111/j.2044-8325.1990.tb00506.X

[81] Baron, R.M. and Kenny, D.A. (1986) The Moderator-Mediator Variable Distinction in Social Psychological Research: Conceptual, Strategic, and Statistical Considerations. Journal of Personality and Social Psychology, 51, 1173-1182. http://dx.doi.org/10.1037/0022-3514.51.6.1173 


\section{Appendix 1}

\section{Psychological Capital}

1) I feel confident analyzing a long-term problem to find a solution.

2) I feel confident discussing my work area with the management.

3) I feel confident contributing for discussions about the bank's strategy.

4) I feel confident helping to set targets/goals in my work area.

5) I feel confident contacting customers to discuss problems.

6) I feel confident presenting information to a group of colleagues.

7) If I should find myself troubled at work I could think of many ways to overcome it.

8) At the present time, I am energetically pursuing my work goals.

9) There are lots of ways around any problem.

10)Right now I see myself as being pretty successful at work.

11)I can think of many ways to reach my current work goals.

12)At this time, I am meeting the work goals that I have set for myself.

13)When I have a setback at work, I have trouble recovering from it, moving on.

14)I usually manage difficulties one way or another at work.

15)I won't hesitate to take my own decision at work if necessary.

16)I usually take stressful things at work in stride.

17)I can get through difficult times at work because I've experienced difficulty before.

18)I feel I can handle many things at a time at this job.

19)When things are uncertain for me at work, I usually expect the best.

20)If something can go wrong for me work-wise, it will.

21)I always look on the bright side of things regarding my job.

22)I'm optimistic about what will happen to me in the future pertaining to work.

23)In this job, things never work out the way I want them to.

24)I approach this job as if "every cloud has a silver lining".

\section{Job Performance}

1) Usually, I contribute to provide a quality service to the customers.

2) I accurately analyze situations and determine the correct course of action.

3) I display well expertise in performing the task related to my job.

4) I make decisions after knowing all the facts regarding my job.

5) I pay attention to detail and avoid making mistakes.

6) I use available resources in a cost-effective manner.

7) I make good decisions in the presence of obstacles.

8) I always produce a high quality standard of work.

9) I comply with instructions even when supervisors are not present.

10) I always work together with others in the team.

11) I persist in overcoming obstacles to complete a task.

12) I consider the bank's reputation as my own honor.

13) I always follow standard procedures and avoid unauthorized shortcuts.

14) I always seek challenging work task necessary for the betterment of the bank.

15) I usually collaborate with colleagues to complete tasks.

16) I pay close attention to important details.

17) I usually focus on the business ethics of the bank.

18) I support and encourage coworkers when they face problems.

19) I take the initiative to accomplish work tasks.

20) I always exercise personal discipline and self-control.

21) I always tackle a difficult work assignment enthusiastically. 


\section{Work Attitudes}

1) I would be very happy to spend the rest of my career with this bank.

2) I enjoy discussing about my bank with people outside it.

3) I really feel as if this bank's problems are my own.

4) I think that I could easily become as attached to another organization as I am to this one.

5) I do not feel like "part of the family" at my bank.

6) I do not feel as I am emotionally attached to this bank.

7) I do not feel a "strong" sense of belonging to my bank.

8) The chance to try out some of my own ideas.

9) The chances to do different things from time to time.

10) The amount of pay for the work I do.

11) The pay compares with similar position in other organization.

12) The opportunities for getting ahead in my position.

13) The policies and practices on promotion.

14) The way my manager handles employees.

15) The way manger communicates and listens to the employees.

16) The way my manager gives opportunity to employees to take part in decision making.

17) The spirit of cooperation among my co-workers.

18) The physical surroundings where I work.

19) The work load of your position. 
Scientific Research Publishing (SCIRP) is one of the largest Open Access journal publishers. It is currently publishing more than 200 open access, online, peer-reviewed journals covering a wide range of academic disciplines. SCIRP serves the worldwide academic communities and contributes to the progress and application of science with its publication.

Other selected journals from SCIRP are listed as below. Submit your manuscript to us via either submit@scirp.org or Online Submission Portal.
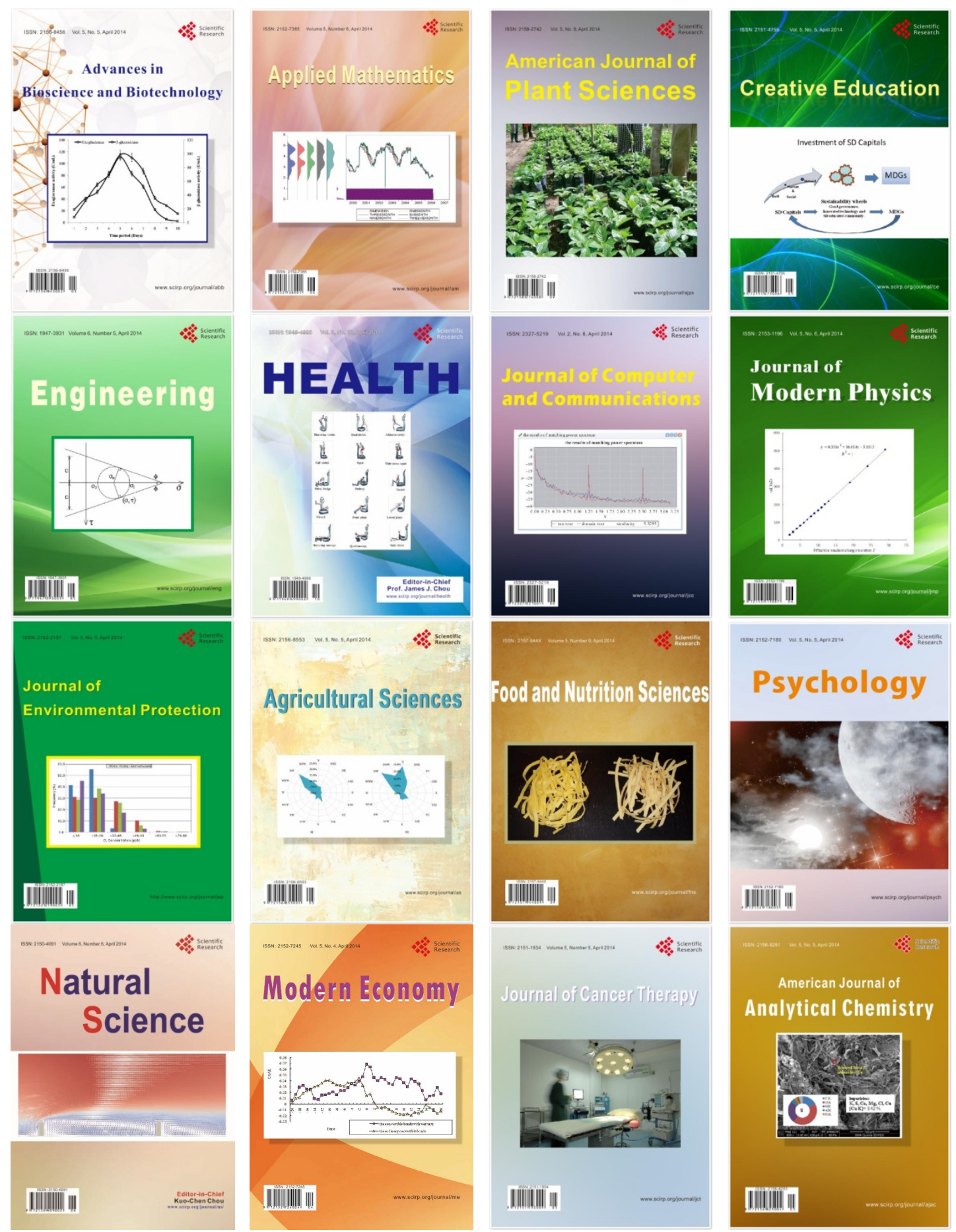